\title{
INFLUENCE OF INTERLEUKIN-6 AND G174C POLYMORPHISM IN IL-6 Gene on OBESITY AND ENERGy BALANCE
}

\author{
K. Popko, E. Gorska, U. Demkow
}

Department of Laboratory Diagnostics and Clinical Immunology of Developmental Age, Warsaw Medical University, Warsaw, Poland

\begin{abstract}
Obesity is a multifactor disease with a very complicated etiology. Genetic factors play an important role in the development of primary obesity. They may be responsible for up to $40 \%$ of causes leading to obesity. There are a great number of genes affecting food intake and energy expenditure. Serious consequences accompanying obesity, e.g., type 2 diabetes and lipid abnormalities may be caused by increased level of proinflammatory cytokines, such as IL-1, IL-6, and TNF. It is possible that polymorphisms located in cytokine genes affect the level of protein expression. It is known that IL-6 plays a role in lipid metabolism and energy expenditure. The polymorphism found in point 174 (G174C) of a promoter region of IL-6 gene affects the level of interleukin-6 expression and, consequently, may lead to obesity and correlated conditions.
\end{abstract}

Key words: obesity, gene polymorphism, IL-6

\section{Biological Functions of Interleukin-6}

For many years biological function of interleukin-6 (IL-6), historically known as interferon beta-2 (IFN- $\beta$ 2) or B cell stimulatory factor-2, was limited to stimulation of B cell proliferation. Protein molecular structure analysis and gene expression studies led to the detailed assessment of IL-6 expression and localization in the organism [1].

Recent studies have shown that up to $30 \%$ of IL-6 in the blood stream is secreted by adipose tissue, and the cytokine level positively correlates with body mass index (BMI) [2, 3]. Intraperitoneal adipocytes secrete three times more IL- 6 than subcutaneous adipose tissue [4]. The published data suggests that the amount of cytokine secreted by adipocytes is related to their size and fat content. Resting adipocytes are able to secrete IL-6, but its expression significantly increases in consequence of glucocorticosteroid or catecholamine activity. TNF secretion is able to induce a 60 -folds increase in IL-6 production [5].

IL-6 is one of major proinflammatory cytokines responsible for immune response activation. Its pleiotropic activity includes the induction of acute phase proteins secretion by liver cells, B-cell differentiation into plasma cells, T-cells activation, and $\mathrm{T}$ cells differentiation into cytotoxic cells. It is observed that in mixed lymphocyte culture (MLC) IL-6 is able to induce a 100-fold increase in the number of cytotoxic T cells. IL-6, synergically with other cytokines, such as IL-3, influences hematopoiesis and platelets formation in bone marrow by the activation of proliferation and differentiation of various hematopoietic lineages stem cells, e.g., megakariocytes, granulocytes, and macrophages $[1,6]$. Moreover, it exerts strong effects on hormonal balance and may induce some endocrinological disturbances. It is suggested that IL-6 may affect the increase of free fatty acids level. IL-6 concentration is elevated in patients with lipid disorders and insulin resistance [7]. Various effects of IL-6 on biochemical parameters are related to IL- 6 concentration, determined by IL-6 gene polymorphisms, influencing both encoding sequence and promoter region.

Some authors suggest that IL-6 can be responsible for the development of several pathophysiological states. A few studies showed that IL-6 is able to induce mesangial cells proliferation in mesangial nephritis. Additionally, increased serum concentration of IL-6 is observed in synovial fluid of rheumatoid arthritis patients [8]. Moreover, IL-6 is able to stimulate proliferation of multiple myeloma cells, which suggests the involvement of this cytokine in the pathogenesis of some neoplasms in humans $[9,10]$. As a result of these observations, IL-6 antagonists have been developed for clinical use.

\section{IL-6 Gene and Protein Structure}

Human IL-6 gene is located on the 7 chromosome at 7p21-p14, between D7S135 and D7S370 [11]. It consists of 5 exons and is $5 \mathrm{~kb}$ long [12]. IL- 6 gene promoter includes numerous regulatory sites allowing the induction of gene expression, e.g., by glucocorticosteroids and cAMP $[13,14]$. An extremely important regulatory site binds $\mathrm{NF}-\mathrm{KB}$, and is responsible for the induction of IL- 6 expression by IL-1 and TNF, mainly in non-lymphoid cells $[15,16]$. Both in the encoding sequence and the promoter, numerous single nucleotide polymorphisms (SNP) were found. One of the most commonly found and analyzed polymorphisms are $C$ (cytosine) to $G$ (guanine) transition at position -174 of the promoter.

IL-6 encoding sequence expression leads to the secretion of a 212 amino acid protein. As a consequence of posttranslational modifications, the protein is shortened and its mature form consists of 185 amino acids and contains two glycosylation sites: at positions -73 and -172 . It has been shown that monocytes, one 
of the major IL- 6 producers, are able to secrete five different molecular forms of the cytokine (21.5 to 28 $\mathrm{kDa}$ ). The isoforms result from posttranslational modifications of precursor proteins including glycosylation and phosphorylation [17-19].

\section{IL-6 RECEPTOR}

IL-6 receptor is an $80 \mathrm{kDa}$ glycosylated protein that consists of 449 amino acids. It is also known as CD 126 molecule. The receptor is synthesized as a 468amino acid length precursor molecule. Its molecular structure is similar to the other cytokine receptors such as M-CSF, PDGF, or IL-11. It contains immunoglobulin-like region in the extracellular domain. The intracellular domain consists of approximately 82 amino acids and is not homologous with other receptors. Two isoforms of the receptor, having various affinity to IL-6 molecules, depending on their concentration $\left(10^{-9}\right.$ and $\left.10^{-11} \mathrm{M}\right)$ are identified. IL-6 biological activity is observed at the concentration of $10^{-13}-10^{-15}$ $\mathrm{M}$, which suggests the presence of the other isoform of the receptor, or at least a high affinity subunit of the receptor. IL-6 receptor transduces the signal through protein kinase $C$ and adenylate cyclase [20, 21]. It has been demonstrated that IL- 6 , together with other cytokines from the same cytokine family, induces signal transduction though the activation of JAK tyrosine kinases [22]. IL-6 binding to the receptor leads to the homodimerization of a transmembrane glycoprotein (gp130) and the activation of tyrosine kinases JAK1, JAK2, Tyk2, STAT1, and STAT3 that induce signal transduction pathways [23]. Additionally, the presence of a soluble IL-6 receptor interfering with gp130 has been demonstrated. The soluble receptor plausibly regulates cytokine activity through the inhibition of IL-6 binding to the surface receptor and also, it can serve as a carrier protein [24].

\section{INFLUENCE OF G174C POLYMORPHISM ON ENERGY BALANCE}

Recent studies concentrate on the influence of IL-6 gene polymorphisms on the development of certain medical conditions. The relation between some genetic variant and the development of obesity seems to be more and more precisely documented.

IL-6 expression is regulated by various factors. IL-1 and TNF induce the expression of IL-6. That explains an increased level of IL- 6 in chronic inflammatory diseases, such as rheumatoid arthritis. On the other hand, steroid hormones such as estradiol or glucocorticosteroids, inhibit IL-6 transcription [25], which is observed in postmenopausal women and may be related to the development of osteoporosis. G/G genotype in G174C polymorphic site of the IL-6 gene promoter region correlates with increased IL- 6 concentration and leads to increases in CRP and the bone resorption marker sCTx (serum C-telopeptide cross-link of type 1 collagen) [26].

The influence of G174C polymorphism on the process of energy expenditure may underlie the role of IL- 6 in the development of obesity and type 2 diabetes. Kubaszek et al [27] have shown that the subject bearing $\mathrm{C} / \mathrm{C}$ genotype are more resistant to insulin and have higher serum glucose concentration. They also have a lower level of energy expenditure and a slightly higher BMI compared with subjects bearing $G$ allele.

The influence of G174C polymorphism on the process of energy expenditure can be explained by various mechanisms. The process is regulated centrally by IL-6 expression in the hypothalamus. In vitro studies have shown that mice bearing inactive IL-6 gene, after central, but not peripheral, administration of exogenous IL-6, increase energy expenditure [28]. In humans, high level of cytokines (including IL-6) and the synthesis of cytokines in brain lead to an increase in resting energy expenditure and may cause cachexy [29]. Peripheral administration of IL-6 causes a dosedependent increase in resting metabolism and the activity of hypothalamus-pituitary gland-suprarenal gland axis, suggesting that corticotropin releasing hormone is intermediary in both processes [30]. Adrenergic stimulation can also be a mechanism of IL- 6 action in the process of energy expenditure. IL-6 causes heart rate acceleration, norepinephrine level increase and sympathetic nervous system stimulation, all being efferent regulators of energy expenditure [31-33]. Moreover, sympathetic neurons express both IL- 6 and IL-6 receptor; hence they are sensitive to IL-6 activity [34]. In renal cancer patients, administration of IL-6 leads to increases in norepinephrine and resting energy expenditure [35].

Another hypothesis includes the possibility of correlation between IL-6 and leptin activities. Animal studies have shown that IL-6 knockout mice are obese and, despite a relatively high leptin level, are insensitive to its effects [28]. Leptin effects on the energy expenditure process are mediated by corticotropin releasing factor that increases energy expenditure and stimulates sympathetic nervous system in rats. Similarly, in humans, exogenous leptin administration increases energy expenditure [36].

The influence of IL- 6 on the regulation of body mass can be connected with the fact that leptin blood level is significantly increased after physical exertion and achieves the maximum value in the final stage of exercise [37]. Moreover, skeletal muscles are the main source of IL-6 produced in response to the increased physical exertion [38]. In addition to muscles, other organs, such as brain or adipose tissue, increase the secretion of IL-6 after physical exertion [39-41]. Numerous studies have demonstrated the increase of IL-6 production in skeletal muscles and its increase in serum in response to physical exertion [8, 42]. Transcriptional activity of IL-6 in muscles is regulated not only by the intensity of physical exertion, but also inversely depends on the glycogen content in active muscles [43]. Administration of carbohydrates during physical exertion results in a decrease of IL-6 serum concentration, but does not change the gene expression level [43]. It is suggested that glucose exerts its action at a posttranslational level, inhibiting cytokine transport.

Some authors also suggest that IL-6 works as a hormone, and that is why it exerts its biological actions during physical exertion. According to this hypothesis, 
IL-6 is secreted by active muscles as a hormonal signal to liver or adipose tissue to activate glycogenolysis or lipolysis [38]. Helge et al [44] have demonstrated a positive correlation between IL-6 secretion and glucose absorption. It is also possible that IL-6 serves as an indicator of carbohydrates availability. A similar relation has been found regarding the influence of physical exertion on adipose tissue metabolism in the studies in which both IL-6 mRNA expression and the cytokine's level increase. However, carbohydrates administration during physical exertion leads to inhibition of IL-6 mRNA expression [45]. That indicates that there are other regulatory pathways for IL- 6 expression in muscles and adipose tissue.

Alleles connected with decreased IL-6 expression can be responsible for the low cytokine's secretion during physical exertion, which can to low level of metabolism, decreased fat burning, and, in consequence, obesity. Recently, the influence of IL-6 on human metabolism is broadly discussed. A connection between IL-6 and carbohydrate or lipid metabolism suggests the cytokine's involvement in the development of obesity and type 2 diabetes. All regulatory functions seem to be related to the cytokine secretion in various tissues in response to external and internal triggers. IL-6 activity can be exerted locally or systemically.

Many authors consider type 2 diabetes and insulin resistance as a symptom of inflammatory response in the organism [7]. The hypothesis can be confirmed by the observation of high levels of acute phase proteins such as CRP, amyloid A, alpha-1-acid glycoprotein, sialic acid, and cortisone in diabetic patients [46, 47]. Moreover, a significant increase in proinflammatory cytokines levels is found in obese population. The increase in IL-6 level, in parallel to increased glucose and insulin concentrations, suggests a possible involvement of the cytokine in glucose metabolism, especially in adipocytes. It is unclear which allele in G174C polymorphic site of IL-6 gene promoter predisposes to the development of type 2 diabetes. Nevertheless, Vozarova et al [48] have demonstrated that allele G may be responsible for high susceptibility to type 2 diabetes. On the other hand, the study performed by Mohling et al [49] in the German population has shown the increased probability of type 2 diabetes development in $\mathrm{C} / \mathrm{C}$ allele carriers. Additionally, studies performed in the Finnish population failed to show any direct relation between polymorphisms and susceptibility to diabetes. However, it has been demonstrated that $\mathrm{C} / \mathrm{C}$ genotype significantly increases the risk of diabetes in patients with the diagnosis of glucose intolerance, carrying allele $\mathrm{A}$ in the G308A polymorphic site in the promoter region of TNF gene [50]. Taken together, data suggest an indirect relation between the genotype and risk of type 2 diabetes.

In non-diabetic subjects, there is a relation between $\mathrm{C} / \mathrm{C}$ genotype and low fasting insulin level and sensitivity to insulin. At the same time, there is a relation between $\mathrm{C} / \mathrm{C}$ genotype and lower serum IL-6 level [50]. In this case, white blood count was an additional marker of peripheral IL-6 activity; the count being significantly lower in subjects bearing $\mathrm{C} / \mathrm{C}$ genotype compared with allele $G$ carriers.
Illig et al [51] have shown a connection between allele $G$ and high risk of type 2 diabetes. Moreover, the authors showed increased levels of MCP-1/CCL-2 in sera obtained from the $\mathrm{C} / \mathrm{C}$ genotype bearing patients. It is well established that increased levels of MCP-1 correlate with a low risk for diabetes. MCP-1 seems a potential factor connecting G174C polymorphism with the susceptibility to diabetes. This connection is seen only in normal weight or slightly overweight males. Similar relations have not been found in females or obese males, which suggests the influence of obesity and hormonal factors in the development of type 2 diabetes. No correlation between G174C polymorphism in IL-6 gene promoter and the development of insulin resistance has been evidenced. The relation between $G 176 \mathrm{C}$ polymorphism and obesity has also been analyzed in obese children, but results are inconclusive [52].

Confusing data obtained by authors studying the influence of G174C polymorphism on the incidence of diabetes and insulin resistance might be explained by difficulties in selection of control and study groups. Type 2 diabetes development depends on numerous factors significantly modulating the risk of disease diagnosis. Apart from various genetic factors, numerous other conditions, such as obesity, glucose tolerance, sex, age, lifestyle, and dietetic habits may influence diabetic status of the patient. This is why a careful selection of analyzed groups seems to be extremely important. As there are so many divergences and uncertainties, there is an urgent need to study associations between polymorphisms of genes encoding proinflammatory cytokine genes and various type 2 diabetes risk factors.

Conflicts of interest: No conflicts of interests were declared by the authors in relation to this article.

\section{REFERENCES}

1. May LT, Ghrayeb J, Santhanam U, Tatter SB, Sthoeger Z, Helfgott DC, Chiorazzi N, Grieninger G, Sehgal PB. Synthesis and secretion of multiple forms of beta 2 -interferon/B-cell differentiation factor 2/hepatocyte-stimulating factor by human fibroblasts and monocytes. J Biol Chem 1988; 263: 7760-6.

2. Mohamed-Ali V, Goodrick S, Rawesh A, Katz DR, Miles JM, Yudkin JS, Klein S, Coppack SW. Subcutanous adipose tissue releases interleukin-6, but not tumor necrosis factor- $\alpha$, in vitro. J Clin Endocrinol Metab 1997; 82: 4196-200.

3. Vgontzas AN, Papanicolaou DA, Bixler DA, Kales A, Tyson K, Chrousos GP. Elevation of plasma cytokines in disorders of excessive daytime sleepiness: role of sleep disturbance and obesity. J Clin Endocrinol Metab 1997; 82: 1313-6.

4. Fried SK, Bunkin DA, Greengerg AS. Omental and subcutaneous adipose tissue of obese subjects release interleukin-6: depot difference and regulation by glucocorticoid. J Clin Endocrinol Metab 1998; 83: 847-50.

5. Grunfeld C, Feingold KR. The metabolic effects of tumor necrosis factor and other cytokines. Biotherapy 1991; 3: 143-58.

6. Hirano T, Yasukawa K, Harada H, Taga T, Watanabe Y, Matsuda T, Kashiwamura S, Nakajima K, Koyama K, Iwamatsu A, Tsunasawa S, Sakiyama F, Matsui H, Takahara Y, Taniguchi T, Kishimoto T. Complementary 
DNA for a novel human interleukin (BSF-2) that induces B lymphocytes to produce immunoglobulin. Nature 1986; 324: $73-76$

7. Pickup JC, Mattock MB, Chusney GD, Burt D. NIDDM as a disease of the innate immune system: Association of acute-phase reactans and interleukin-6 with metabolic syndrome X. Diabetologia 1997; 40: 1286-92.

8. Steensberg A, Febbraio MA, Osada T, Schjerling P, van Hall G, Saltin B, Pedersen BK. Interleukin-6 production in contracting human skeletal muscle is influenced by preexercise muscle glycogen content. J Physiol 2001; 537: 633-9.

9. Kawano M, Hirano T, Matsuda T, Taga T, Horii Y, Iwato K, Asaoku H, Tang B, Tanabe O, Tanaka H. Autocrine generation and requirement of BSF-2/IL- 6 for human multiple myelomas. Nature 1988; 332: 83-5.

10. Filella X, Blade J, Montoto S, Molina R, Coca F, Montserrat E, Ballesta AM. Impaired production of interleukin-6 and tumour necrosis factor alpha in whole blood cell cultures of patients with multiple myeloma. Cytokine 1998; 10: 993-6.

11. Shimabukuro M, Koyama K, Chen G, Wang MY, Trieu F, Lee Y. Newgard CB, Unger RH. Direct antidiabetic effect of leptin trough triglyceride depletion of tissues. Proc Natl Acad Sci USA 1997; 94: 4637-41.

12. Stunkard AJ. An adoption study of human obesity. N Engl J Med 1986; 314: 193-8.

13. White DW, Wang Y, Chua SC. Constitutive and impaired signalling of leptin receptors containing the Gln $\rightarrow$ Pro extracellular domain fatty mutation. Proc Natl Acad Sci USA 1997; 94: 10657-62.

14. Gotoda T, Manning BS, Goldstone AP. Leptin receptor gene variation and obesity: lack of association in a white British male population. Hum Mol Genet 1997; 6: 869876.

15. Wu DM, Shen MH, Chu NF. Relationship between plasma leptin levels and lipid profiles among school children in Taiwan-the Taipei Children Heart Study. Eur J Epidemiol 2001; 17: 911-6.

16. Kroder G, Bassenmaier B, Kellerer M, Capp E, Stoyanov B, Muhlhofer A, Berti L, Horikoshi H, Ulrich A, Haring $\mathrm{H}$. Tumor necrosis factor alpha and hyperglycemia-induced insulin resistance: evidence for different mechanism and different effects on insulin signaling. J Clin Invest 1996; 97: 1471-7.

17. Van Damme J, Van Beeumen J, Decock B, Van Snick J, De Ley M, Billiau A. Separation and comparison of two monokines with lymphocyte-activating factor activity: IL1 beta and hybridoma growth factor (HGF). Identification of leukocyte-derived HGF as IL-6. J Immunol 1988; 140: 1534-41.

18. Breton J, la Fiura A, Bertolero F, Orsini G, Valsasina B, Ziliotto R, de Filippis V, Polverino de Laureto P, Fontana A. Structure, stability and biological properties of a $\mathrm{N}$-terminally truncated form of recombinant human interleukin-6 containing a single disulfide bond. Eur J Biochem 1995; 227: 573-81.

19. Somers W, Stahl M, Seehra JS. 1.9 A crystal structure of interleukin-6: implications for a novel mode of receptor dimerization and signaling. EMBO 1997; 16: 98997.

20. Simpson RJ, Hammacher A, Smith DK, Matthews JM, Ward LD. Interleukin-6: Structure-function relationships. Protein Sci 1997; 6: 929-55.

21. Yamasaki K, Taga T, Hirata Y, Yawata H, Kawanishi Y, Seed B, Taniguchi T, Hirano T, Kishimoto T. Cloning and expression of the human interleukin-6 (BSF-2/IFN beta 2) receptor. Science 1988; 241: 825-8.

22. Ihle JN, Kerr IM. Jaks and Stats in signaling by the cytokine receptor superfamily. Trends Genet 1995; 11: 6974.
23. Taga T, Hibi M, Hirata Y, Yamasaki K, Yasukawa K, Matsuda T, Hirano T, Kishimoto T. Interleukin-6 triggers the association of its receptor with a possible signal transducer, gp130. Cell 1989; 58: 573-81.

24. Yasukawa K, Futatsugi K, Saito T, Yawata H, Narazaki M, Suzuki H, Taga T, Kishimoto T. Association of recombinant soluble IL-6-signal transducer, gp130, with a complex of IL-6 receptor, and establishment of an ELISA for soluble gp130. Immunol Lett 1992; 31: 123 30.

25. Ray A, Prefontaine KE, Ray P. Down-modulation of interleukin- 6 gene expression by 17 beta-estradiol in the absence of high affinity DNA binding by the estrogen receptor. J Biol Chem 1994; 269: 12940-6.

26. Ferrari SL, Ahn-Luong L, Garnero P, Humphries SE, Greenspan SL. Two promoter polymorphisms regulating interleukin-6 gene expression are associated with circulating levels of C-reactive protein and markers of bone resorption in postmenopausal women. J Clin Endocrinol Met 2003; 88: 255-9.

27. Kubaszek A, Pihlajamaki J, Komarovski V, Lindi V, Lindstrom J, Eriksson J, Valle TT, Hamalainen H, IlanneParikka P, Keinanen-Kiukaanniemi S, Tuomilehto J, Uusitupa M, Laakso M. Promoter polymorphisms of the TNF-alpha (G-308A) and IL-6 (C-174G) genes predict the conversion from impaired glucose tolerance to type 2 diabetes: The Finnish Diabetes Prevention Study. Diabetes 2003; 52: 1872-6.

28. Wallenius V, Wallenius K, Ahren B, Rudling M, Carlsten H, Dickson SL, Ohlsson C, Jansson J-O. Interleukin-6 deficient mice develop mature-onset obesity. Nature Med 2002; 8, 75-9.

29. Plata-Salaman CR. Central nervous system mechanisms contributing to the cachexia-anorexia syndrome. Nutrition 2000; 16: 1009-12.

30. Tsigos C, Papanicolaou DA, Defensor R, Mitsidis CS, Kyrou I, Chrousos GP. Dose effects of recombinant human interleukin-6 on pituitary hormone secretion and energy expenditure. Neuroendocrinology 1997; 66: 5462.

31. Torpy DJ, Papanicolaou DA, Lotsikas AJ, Wilder RL, Chrousos GP, Pillemer SR. Responses of the sympathetic nervous system and the hypothalamic-pituitary-adrenal axis to interleukin-6: a pilot study in fibromyalgia. Arthritis Rheum 2000; 43: 872-880.

32. Fernandes-Real JM, Vayreda M, Richart C, Gutierrez C, Broch M, Vendrell J, Ricart W. Circulating interleukin-6 levels, blood pressure, and insulin sensitivity in apparently healthy men and women. I Clin Endocrinol Metab 2001; 86: $1154-9$

33. Papanicolaou DA, Petrides JS, Tsigos C, Bina S, Kalogeras KT, Wilder R, Gold PW, Deuster PA, Chrousos GP. Exercise stimulates interleukin-6 secretion: Inhibition by glucocorticoids and correlation with catecholamines. Am J Physiol 1996; 271: E601-5.

34. Marz P, Cheng JG, Gadient RA, Patterson PH, Stovan T, Otten U, Rose-John S. Sympathetic neurons can produce and respond to interleukin-6. Proc Natl Acad Sci USA 1998; 95: 3251-6.

35. Stouthard JM, Romijn JA, Van der Poll T, Endert E, Klein S, Bakker PJ, Veenhof CH, Sauerwein HP. Endocrinologic and metabolic effects of interleukin- 6 in humans. Am J Physiol 1995; 268: E813-9.

36. Rosenbaum M, Murphy EM, Heymsfield SB, Matthews DE, Leiber RL. Low dose leptin administration reverses effects of sustained weight-reduction on energy expenditure and circulating concentrations of thyroid hormones. J Clin Endocrinol Metab 2002; 87: 2391-4.

37. Pedersen BK, Hoffman-Goetz L. Exercise and the immune system: Regulation, integration and adoption. Physiol Rev 2000; 80: 1055-81. 
38. Steensberg A, van Hall G, Osada T, Sacchetti M, Saltin B, Pedersen BK. Production of IL- 6 in contracting human skeletal muscles can account for the exercise-induced increase in plasma IL-6. J Physiol 2000; 529: 237-42.

39. Nybo L, Nielsen B, Pedersen BK, Moller K, Secher NH. Interleukin-6 release from the human brain during prolonged exercise. J Physiol 2002; 542: 991-5.

40. Langberg H, Olesen J, Gemmer C, Kiaer M. Substantial elevation of interleukin- 6 concentration in peritendinous tissue, in contrast to muscle, following prolonged exercise in humans. J Physiol 2002; 542: 985-90.

41. Lyngso D, Simonsen L, Bulow J. Interleukin-6 production in human subcutaneous abdominal adipose tissue: the effect of exercise. J Physiol 2002; 543: 373-8.

42. Ostrowski K, Rodher T, Zacho M, ASP S, Pedersen BK. Evidence that interleukin- 6 produced in human skeletal muscle during prolonged running. J Physiol 1998; 508: 949-53.

43. Keller C, Steensberg A, Pilegaard H, Osada T, Saltin B, Pedersen BK, Neufer PD. Transcriptional activation of the IL- 6 gene in human contracting skeletal muscle: influence of muscle glycogen content. FASEB J 2001; 15: 2748-50.

44. Helge JW, Stallknecht B, Pedersen BK, Galbo H, Kiens $\mathrm{B}$, Richter EA. The effect of graded exercise on IL-6 release and glucose uptake in human skeletal muscle. J Physiol 2003; 546, 299-305.

45. Keller C, Keller P, Marshal S, Pedersen BK. IL-6 gene expression in human adipose tissue in response to exerciseeffect of carbohydrate ingestion. J Physiol 2003; 550: $927-$ 31.

46. Jonsson A, Wales JK. Blood glycoprotein levels in diabetes mellitus. Diabetologia 1976; 12: 245-50.

47. McMillan DE. Increased levels of acute-phase serum proteins in diabetes. Metabolism 1989; 38: 1042-6.
48. Vozarova B, Fernandez-Real JM, Knowler WC, Gallart L, Hanson RL, Gruber JD, Ricart W, Vwndrell J, Richart C, Tataranni PA, Wolford JK. The interleukin-6 (-174) G/C promoter polymorphism is associated with type- 2 diabetes mellitus in Native Americans and Caucasians. HumGenet 2003; 112: 409-13.

49. Mohlig M, Boeing H, Spranger J, Osterhoff M, Kroke A, Fisher E, Bergmann MM, Ristow M, Hoffmann K, Pfeiffer AF. Body mass index and C-174G interleukin-6 promoter polymorphism interact in predicting type 2 diabetes. J Clin Endocrinol Metab 2004; 89: 1885-90.

50. Fernandez-Real JM, Broch M, Vendrell J, Gutierrez C, Casamitjana R, Pugeat M, Richart C, Ricart W. Interleukin-6 gene polymorphism and insulin sensitivity. Diabetes 2000; 49: 517-20.

51. Illing T, Bongardt F, Schopfer A, Muller-Scholce S, Rathmann W, Koenig W, Thorand B, Vollmert C, Holle R, Kolb H, Herder C. Significant association of the interleukin-6 gene polymorphism C-174G and A-598G with type 2 diabetes. J Clin Endocrinol Metab 2004; 89: 50538.

52. Popko K, Gorska E, Stelmaszczyk-Emmel A, Wisniewska A, Majcher A, Wasik M, Demkow U. Influence of proinflammatory cytokine gene polymorphism on childhood obesity. Eur J Med Res 2009; 14 Supp 4, 59-62.

Address for correspondence:

Katarzyna Popko

24, Marszalkowska St.

00-576 Warsaw

Poland

Phone/fax: +48 226296517

E-mail: aksiak@interia.pl 